\title{
Сучасні проблеми менеджменту у спортивній сфері
}

\author{
${ }^{1}$ Юлія Леонова \\ ${ }^{2}$ Тетяна Дорофєєва
}

\author{
${ }^{1}$ Харківська державна академія фрізичної культури, \\ Харків, Україна \\ ${ }^{2}$ Харківський національний педагогічний \\ університет імені Г.С. Сковороди, Харків, Україна
}

\begin{abstract}
Мета: виявити та описати сучасні проблеми менеджменту у вітчизняній спортивній сфері.
Матеріал і методи: теоретичнітапрактичнідослідженнявітчизнянихвчених, науковалітература;методипорівняння, синтезу, аналізу.

Результати: було встановлено, що для ефрективного вирішення виявлених проблем необхідно удосконалити вітчизняне законодавство; створити спеціальну групу фахівців, що протягом останнього часу придбали практичний досвід менеджменту і юридичного регулювання професійного спорту; переорієнтувати систему з утримання об'єктів на розвиток людей.
\end{abstract}

Висновки: було виявлено та описано основні проблеми менеджменту у вітчизняній спортивній сфрері. Також було названо напрямки ефрективного вирішення виявлених проблем.

Ключові слова: менеджмент, спортивна сфрера, фрізична культура, фрізичне виховання, спортсмени, спонсорство, спортивні менеджери.

\section{Вступ}

Актуальність дослідження зумовлена необхідністю негайного та ефективного розвитку сфрер професійного та масового спорту в Україні. Основним підтвердженням рівня розвитку спорту в Україні є: здоров'я різних верств населення, ступінь використання фізичної культури в різних сферах діяльності людей, розвиток системи фрізичного виховання, масовість самодіяльного спорту, високі досягнення спортсменів України в окремих видах спорту, рівень забезпеченості кваліфікованими кадрами, спортивними спорудами та майном. Окремі питання ефективності менеджменту в спорті проаналізовані в роботах таких вчених, як: Д. Бондар, С. Брякін, Н. Візітей, В. Столяров, В. Білогур, М. Ібрагімов та інших. Необхідність підвищення ефективності менеджменту в спорті зумовлюється особливостями галузі, зокрема тим, що у фрізичній культурі виникає потреба одночасного вирішення питань спортивного, фрінансового, психологічного характеру з організації спортивного процесу, а також безпосередньої участі у ньому суб'єктів та об'єктів спортивної галузі [1].

Мета роботи - виявити та описати сучасні проблеми менеджменту у вітчизняній спортивній сфрері.

Завдання дослідження:

дослідити існуючі проблеми менеджменту у вітчизняній спортивній сфрері;

визначити основні напрямки ефективного вирішення виявлених проблем.

\section{Матеріал і методидослідження}

Теоретичні та практичні дослідження вітчизняних вчених, наукова література; методи порівняння, синтезу, аналізу.

\section{Результати дослідження}

Проблеми менеджменту у вітчизняній спортивній сфері визначаються застарілою матеріально-технічною базою, недостатнім фінансуванням фрізичної культури і спорту бюджетними організаціями різних рівнів, відсутністю ефрективної системи законодавчих актів про подат-ки, пільги, меценатство і спонсорство, телевізійне право та ін. Усе це виявляється у недопідготовці професійних спортсменів, відсутності дитячо-юнацького спорту, низьких результатах у різних змаганнях у межах Європи, Світу й Олімпійських ігор. Специфріка українського спорту полягає в тому, що доходи від телетрансляцій, реклами, продажів сезонних абонентів і клубної атрибутики скла- дають незначну частину бюджетів спортивних організа- цій. Практично не розкритий потенціал корпоративного сегменту, що у Європі стає одним із ключових споживачів спортивного шоу, рідко застосовується і продаж ліцензій на використання бренда спортивного клубу. Найдохідні- ша стаття українських клубів - це участь у змаганнях Європейського і світового рівня. Але це доступно не всім клубам і спортсменам, основне навантаження поки приходиться на спонсорів і акціонерів [2].

Необхідною умовою успішного функціонування спортивних клубів, фредерацій, комітетів і окремих спортсме- нів $\epsilon$ створення позитивного уявлення про себе і свою діяльність. Створення сприятливого іміджу своєї організації та високий спортивний розряд значною мірою допомагає учасникам економічних відносин у спортивній сфері вирішувати такі завдання [3]:

залучення спонсорів, додаткових уболівальників, молодих і вже сформованих спортсменів і тренерів;

встановлення ефрективних контактів із засобами масової інформації, зарубіжними організаціями і держав- ними органами.

Реклама спортивних клубів і організацій з позитив- ним іміджем, їх емблем i товарних знаків сприймається рекламодавцями 3 великою довірою. Принциповою відмінністю українського спонсорства від зарубіжного $є$ те, що воно часто не окупається за рахунок реклами, яка 


\section{СЛОБОЖАНСЬКИЙ НАУКОВО-СПОРТИВНИЙ ВІСНИК:}

\section{Матеріали XIX Міжнародної науково-практичної конференції «Фізична культура, спорт і здоров'я: стан, проблеми та перспективи»}

надається спонсорами. Можна зазначити, що в умовах ринкової економіки спорт стає різновидом бізнесу внаслідок того, що спортивні організації не в змозі забезпечити свою фінансову самостійність і змушені вдаватися до фінансових впливів зі сторони, розплачуючись за це рекламою чужої продукції. Одночасно компаніям і фрірмам вигідно спонсорувати спорт, оскільки відносно невеликі спонсорські суми порівняно з витратами на рекламу нерідко дають незрівнянно відчутніший результат. Також суттєвою перешкодою на шляху залучення іноземних і вітчизняних інвесторів у спортивну сферу є досить недосконале вітчизняне законодавство [4;5].

У спортивних організаціях якскладнихсоціальнихсистемах репрезентується певний розподіл праці, в контексті якого спортивні менеджери виконують такі функції [1; 6]:

функції прийняття рішень (менеджер визначає напрямок діяльності організації та вирішує питання розподілу ресурсів. Право прийняття рішень має тільки менеджер, який несе персональну відповідальність за прийняття рішень);

інформаційна фрункція (менеджер збирає інфрормацію про внутрішнє і зовнішнє середовище фрізкультурноспортивної спрямованості, розповсюджує цю інфрормацію у вигляді фактів та установок, роз'яснює персоналуполітику, філософрію та місію, найближчі та перспективні цілі спортивної організації);

управлінська функція керівника (менеджер формує відносини всередині організації, мотивує діяльність, координує зусилля членів організації, виступає у якості представника організації у взаємодії з іншими організаціями).

Щоб розвивати бізнес спорту шляхом утримання конкурентної переваги у своїй діяльності менеджер повинен вдаватися до адекватних стратегічних та оперативних змін на засадах комплексного підходу до формування конкурентних переваг того чи іншого виду спортивної діяльності [4; 7]:

застосування комплексного, системного та інноваційного підходів до розвитку спортивної організації;

забезпечення єдності розвитку техніки, технології, економіки та спортивного менеджменту;

застосування новітніх методів управління (функціонально-вартісний аналіз, моделювання та прогнозування, оптимізація та економічне обґрунтування спортивних рішень, програмно-цільове планування).

Конкурентні переваги у сфері спорту не є довготривалими, вони завойовуються та утримуються тільки завдяки постійному вдосконаленню свого видуспорту.

Узагальнення зарубіжного досвіду свідчить, що спортивні клуби $є$ основною організаційною формою менеджменту у сфрері фрізичного виховання і спорту в більшості розвинених країн світу. В зарубіжних країнах поряд з популярними клубами професіонального фрутболу, хокею та інших ігрових видів спорту функціонують численні спортивні клуби оздоровчого напрямку. В Україні ж клуби оздоровчого характеру тільки починають розвиватися. Тому необхідно дослідити моделі фрункціонування клубів зарубіжних країн і прийняти їх досвід у побудові фрізкультурно-спортивних організацій в Україні [2; 8]. У США, Німеччині, Японії моделі менеджменту сформовані на основі традицій та національної культури, і вони $€$ ефрективними. Українським менеджерам не слід орієнтуватися на зарубіжні організації, тобто впроваджувати ідентичні моделі у свій бізнес. Успіх цих моделей зумов- лений об'єктивними чинниками, які виходять зі специфіки країн. Варто вивчати зарубіжний досвід, аналізувати його, співвідносити з особливостями вітчизняного менеджменту, і на основі висновків розробити і впровадити власну модель.

Проведений аналіз свідчить про те, що Україні більше підходить європейська модель розвитку. Ії̈ головна особливість полягає в певному балансі інтересів держави, підприємств, їх власників, профспілок та інших громадських організацій. Крім того, європейська модель (як американська та японська) включає високий рівень заробітної плати та продуктивності праці. Але на відміну від американської в ній вищий ступінь соціального забезпечення населення, а від японської - прозоре конкурентне середовище. Також їй властива ефективна система управління в масштабі всього суспільства, а не тільки на окремих підприємствах [2;9].

Моментальний перехід на нову модель можливий, але за наявності великих витрат. Такий перехід, особливо в умовах економічної кризи в країні, відсутності профресіоналів і великого впливу політиків, негативно позначиться на самій індустрії спорту і на більшості фрахівців. Поступове ж виключення елементів, що створюють труднощі, зловживання і непрофесіоналізм з індустрії, можуть призвести до створення умов для впровадження нової моделі спорту в Україні. Для вирішення виявлених проблем необхідно запросити до управління сферою культури молодих фахівців з хорошою освітою, новими ідеями, вони повинні володіти навичками в менеджменті та знаннями ринкової економіки. Також надати їм можливість формувати свою команду і в той же час нести відповідальність за свій сектор роботи. Вирішальним з точки зору розвитку масового спорту буде не стільки рішення конкретного чиновника чи директива міністерства, скільки певний громадський тренд, який буде виступати елементом тиску на владу. Він в Україні існує (зростає кількість фрітнес-клубів, благодійних марафонів), але цей рух ще не набрав критичної маси, яка б була здатна відстоювати цю позицію. Держава має активно впливати на фоомування попиту на спортивно-оздоровчі послуги і формувати відповідний механізм впливу на суспільство, який включає філософські, морально-етичні, соціально-психологічні, економічні та інші засоби, які спонукають людей до активних занять фрізичною культурою і спортом [4].

Якщо говорити про залучення фрінансових коштів в український спорт через маркетингове управління, то необхідно перейти від просто створення змагань до створення спортивних подій тому, що саме вони у світовій спортивній індустрії мають маркетинговий потенціал для світових брендів. Якісні спортивні події цікаві тим, що рекламна інфрормація про продукт, розміщена в періодпроведення змагань, потрапляє безпосередньо до кінцевого споживача продуктів, тієї цільової аудиторії, що здатна зібрати спортивна подія, організована на видовищному та інформаційному рівні $[6 ; 10]$.

Професійний спорт $€$ комерційним напрямком діяльності у спорті, який пов'язаний з підготовкою та проведенням видовищних спортивних заходів на високо- му організаційному рівні 3 метою отримання прибутку. Спортсмен набуває статусу спортсмена-професіонала з моменту укладення контракту з відповідними суб'єктами сфери фрізичної культури і спорту про участь у змаганнях серед спортсменів-професіоналів. Порядок визнання видів спорту в Україні, включення їх до відповідного реєстру 


\section{СЛОБОЖАНСЬКИЙ НАУКОВО-СПОРТИВНИЙ ВІСНИК:}

\section{Матеріали XIX Міжнародної науково-практичної конференції «Фізична культура, спорт і здоров'я: стан, проблеми та}

та порядок ведення цього реєстру визначаються центральним органом виконавчої влади. В Україні не можуть визнаватися види спорту, які пов'язані з небезпекою чи надмірним ризиком для життя і здоров'я людей або мають антигуманний зміст.

Станом на 2018 рік в Україні функціонує 1687 дитячоюнацьких спортивних шкіл (ДЮСШ) різних форм власності та підпорядкування, в яких налічується більше півмільйона вихованців віком від 6 до 18 років. До занять у спортивних школах також залучено 6,5 тис. дітей-інвалідів різних нозологій [1].

У цілому, 191 спортивна школа має статус спеціалізованої школи олімпійського резерву. Кращі вихованці беруть участь на Всеукраїнських змаганнях серед учнів ДЮСШ. Спеціалізовані навчальні заклади спортивного профрілю діють у 13 регіонах країни з них [1]:

9 вищих училищ фрізичної культури;

3 училища олімпійського резерву;

4 ліцеї-інтернати спортивного профрілю;

2 школи-інтернати спортивного профрілю.

У спеціалізованих закладах культивується 37 олімпійських видів спорту і займається 5,5 тис. спортсменів Кожен п'ятий вихованець цих закладів входить до складу національних збірних команд України з олімпійських видів спорту. Відповідно до Єдиного календарного плану фрізкультурно-оздоровчих та спортивних заходів з метою масового залучення дітей та підлітків до регулярних занять фізичною культурою і спортом та підвищення їхньої рухової активності систематично проводяться спортивно-масові та фрізкультурно-оздоровчі заходи по всій Україні («Старти надій», «Ігри Чемпіонів» та інші) Проблемним питанням залишається фінансування та сучасне оснащення спеціалізованих навчальних закладів спортивного профілю, а також визначення нової методології фрізичного виховання дітей та молоді [2].

Перелік показників стану розвитку фізичної культури спорту затверджує центральний орган виконавчої влади, що забезпечує формування державної політики у сфері фрізичної культури та спорту. Зокрема, до такого переліку включаються показники рівня [4]:

фізичного здоров'я різних груп населення;

залучення громадян до занять масовим спортом;

залучення осіб з інвалідністю до занять фрізкультурноспортивною реабілітацією;

залучення дітей та молоді, у тому числі дітей та молоді з інвалідністю, до занять у дитячо-юнацьких спортивних школах;

забезпеченості кадрами сфери фрізичної культури спорту;

фінансового та матеріально-технічного забезпечення сфери фізичної культури і спорту;

досягнень спортсменів України на міжнародних спортивних змаганнях, передусім Олімпійських, Паралімпійських і Дефлімпійських іграх, Глобальних іграх спортсменів з порушенням інтелекту, Всесвітніх іграх з неолімпійських видів спорту;

створення умов для доступу осіб з інвалідністю до спортивних споруд.

Зазначені показники враховуються для моніторингу стану розвитку фрізичної культури і спорту, розроблення програм їх розвитку, інших нормативно-правових актів у цій сорері.

Фінансування розвитку фізичної культури і спор- ту здійснюється відповідно до Закону України та інших нормативно-правових актів за рахунок коштів відповідно державного та місцевого бюджетів, а також інших джерел, не заборонених законодавством. Для розвитку фізичної культури і спорту використовуються позабюджетні кошти, зокрема від [5]:

підприємств, установ та організацій, об'єднань громадян, окремих осіб;

фінансово-господарської діяльності закладів фізичної культури іспорту;

користування правами інтелектуальної власності закладами фрізичної культури і спорту, організаторами фрізкультурно-оздоровчих та спортивних заходів;

проведення державної спортивної лотереї; інвестиційної діяльності у сфері фрізичної культури і спорту.

На розвиток фрізичної культури і спорту підприємства, установи та організації спрямовують кошти у порядку, визначеному законодавством. Заклади фізичної культури і спорту звільняються від сплати земельного податку відповідно до закону. Держава може надавати податкові пільги для юридичних та фрізичних осіб (резидентів та нерезидентів), що здійснюють благодійну діяльність у сфрері фрізичної культури і спорту в порядку, визначеному законодавством. У сільській місцевості витрати на утримання закладів фізичної культури і спорту, в тому числі ДЮСШ, а також на проведення фізкультурноспортивних заходів здійснюються відповідно до закону. Держава сприяє діяльності суб'єктів господарювання, що здійснюють інвестиційну діяльність у сорері фрізичної культури і спорту в Україні[1].

До основних завдань статистичних спостережень у сорері фрізичної культури і спорту належать [1]:

збирання, розроблення, узагальнення та всебічний аналіз статистичної інформації щодо подій у сфері фрізичної культури і спорту;

розроблення і впровадження статистичної методології, що базується на результатах наукових досліджень, міжнародних стандартах та рекомендаціях;

забезпечення достовірності, об'єктивності, оперативності, стабільності та цілісності статистичної інформації;

забезпечення доступності, гласності та відкритості зведених статистичних даних у межах законодавства.

Порядок подання та перелік показників статистичних спостережень у сфері фрізичної культури і спорту встановлюються центральним органом виконавчої влади, що забезпечує формування державної політики у сфері статистики, з урахуванням пропозицій центрального органу виконавчої влади, що реалізує державну політику у сфері фрізичної культури та спорту.

Для ефективного вирішення виявлених проблем необхідно удосконалити вітчизняне законодавство; створити спеціальну групу фахівців, що протягом останнього часу придбали практичний досвід менеджменту і юридичного регулювання професійного спорту; переорієнтувати систему з утримання об'єктів на розвиток людей.

\section{Висновки /Дискусія}

Отже, фізична культура і спорт є засобами фізичного розвитку людини, укріплення здоров'я, виявлення соціальної активності людей, формою організації і проведення дозвілля. У роботі було виявлено та описано основні проблеми менеджменту у вітчизняній спортивній сфері. 


\section{СЛОБОЖАНСЬКИЙ НАУКОВО-СПОРТИВНИЙ ВІСНИК:}

\section{Матеріали XIX Міжнародної науково-практичної конференції «Фізична культура, спорт і здоров'я: стан, проблеми та перспективи»}

Також було названо напрямки ефективного вирішення виявлених проблем. Подальшому дослідженню підлягає вивчення основних підходів до підвищення ефективності менеджменту у спортивній сфері.

Конфлікт інтересів. Автори заявляють, що немає конфрлікту інтересів, який може сприйматися таким, що може нанести шкоду неупередженості статті.

Джерела фінансування. Ця стаття не отримала фінансової підтримки від державної, громадської або комерційної організації.

\section{Список посилань}

1. Бачинская Н. В., Сарычев В. И. (2018), "Олимпийский и профессиональный спорт в Украине: проблемы и перспективы", Вестник Днепропетровского национального университета имени Олеся Гончара, № 2 (48), С. 98-103.

2. НеродаН.Н. (2016), "Характеристика європейської моделі професійного спорту таїї відмінності від американської", Спортивна наука України, № 2 (72), С. 68-72.

3. Нікітенко С. В. (2016), "Особливості фрінансування фрізичної культури та спорту в Україні", Державне управління, №1 (53), С. 54-58.

4. Стахів І. М. (2014), "Основні засади державного регулювання спортивно-оздоровчих послуг", Економічний фрорум, № 4, С. 24-29.

5. Сітнікова Н. С. (2014), "Сучасний стан фінансування Олімпійського руху в Україні", Державне управління, № 1, С. 34-38.

6. Alexander R. (2015), Marketing Definitions : a Glossary of Terms, McGraw-Hill, Chicago.

7. Bairner A. (2014), Sport, nationalism, and globalization: European and North American perspectives, State University of New York Press, Albany.

8. Crouhy M., Galai D., Mark R. (2016), Risk Management, McGraw-Hill, New York.

9. Damodaran A. (2016), Strategic Risk Taking: A Framework for Risk Management, Pearson Prentice Hall, Pennsylvania.

10. Jarvie G., Maguire J. (2014), Sport and Leisure in Social Thought, Routledge, London.

Стаття надійшла до редакції: 11.11.2019 р.

Опубліковано: 30.12.2019 р.

Аннотация. Юлия Леонова, Татьяна Дорофеева. Современные проблемы менеджмента в спортивной сфере. Цель работы: выявить и описать современные проблемы менеджмента в отечественной спортивной сфере. Материал и методы исследования: теоретические и практические исследования отечественных ученых, научная литература; методы сравнения, синтеза, анализа. Результаты: было установлено, что для эффеективного решения выявленных проблем необходимо усовершенствовать отечественное законодательство; создать специальную группу профессионалов, которые в течение последнего времени приобрели практический опыт менеджмента и юридического регулирования профрессионального спорта; переориентировать систему с содержания объектов на развитие людей. Выводы: были выявлены и описаны основные проблемы менеджмента в отечественной спортивной сфере. Также были названы направления эффрективного решения выявленных проблем.

Ключевые слова: менеджмент, спортивная сфера, ффизическая культура, физическое воспитание, спортсмены, спонсортсво, спортивные менеджеры

Abstract. Julia Leonova, Tatyana Dorofieieva. Modern problems of management in the sports field. The purpose of work: to identify and describe modern problems of management in the domestic sports sphere. Material and methods of research: theoretical and practical researches of domestic scientists, scientific literature; methods of comparison, synthesis, analysis. Results: it was found that domestic legislation needed to be improved to effectively address the problems identified; create a special group of professionals who have recently acquired practical experience in the management and legal regulation of professional sports; reorient the system from facility maintenance to people development. Conclusions: the main problems of management in the domestic sports sphere were identified and described. The directions of effective solution of the identified problems were also mentioned.

Keywords: management, sports, physical education, physical education, athletes, sponsorship, sports managers

\section{References}

1. Bachinskaya N. V., Sarychev V. I. (2018), "Olimpiyskiy i professional'nyy sport v Ukraine: problemy i perspektivy", Vestnik Dnepropetrovskogo natsional'nogo universiteta imeni Olesya Gonchara, № 2 (48), pp. 98-103. (in Russ.)

2. Neroda N. N. (2016), "Kharakterystyka yevropeiskoi modeli profesiinoho sportu ta yii vidminnosti vid amerykanskoi", Sportyvna nauka Ukrainy, № 2 (72), pp. 68-72 (in Ukr.).

3. Nikitenko S. V. (2016), "Osoblyvosti finansuvannia fizychnoi kultury ta sportu v Ukraini", Derzhavne upravlinnia, №1 (53), pp. 54-58. (in Ukr.).

4. Stakhiv I. M. (2014), "Osnovni zasady derzhavnoho rehuliuvannia sportyvno-ozdorovchykh posluh", Ekonomichnyi forum, № 4, pp. 2429. (in Ukr.).

5. Sitnikova N. S. (2014), "Suchasnyi stan finansuvannia Olimpiiskoho rukhu v Ukraini", Derzhavne upravlinnia, № 1, pp. 34-38. (in Ukr.).

6. Alexander R. (2015), Marketing Definitions : a Glossary of Terms, McGraw-Hill, Chicago. (in Eng.)

7. Bairner A. (2014), Sport, nationalism, and globalization: European and North American perspectives, State University of New York

Press, Albany. (in Eng.)

8. Crouhy M., Galai D. and Mark R. (2016), Risk Management, McGraw-Hill, New York. (in Eng.)

9. Damodaran A. (2016), Strategic Risk Taking: A Framework for Risk Management, Pearson Prentice Hall, Pennsylvania. (in Eng.)

10. Jarvie G. and Maguire J. (2014), Sport and Leisure in Social Thought, Routledge, London. (in Eng.)

Received: 11.11 .2019 .

Published: 30.12 .2019 .

\section{Відомості про авторів / Information about the Authors}

Леонова Юлія Олександрівна, кандидат економічних наук, доцент, Харківська державна академія фрізичної культури, адреса: вул. Клочківська, буд. 99, м. Харків, Україна, 61058

Leonova Yuliia Oleksandrivna, Ph.D in Economics, assistant professor, Kharkiv State Academy of Physical Culture 


\section{СЛОБОЖАНСЬКИЙ НАУКОВО-СПОРТИВНИЙ ВІСНИК:}

\section{Матеріали XIX Міжнародної науково-практичної конференції «Фізична культура, спорт і здоров'я: стан, проблеми та}

Klochkivska St, 99, Kharkiv, Kharkiv Oblast, Ukraine, 61058

Леонова Юлия Александровна, кандидат экономических наук, доцент, Харьковская государственная академия физической культуры, адрес: ул. Клочковская, д. 99, г. Харьков, Украина, 61058

ORCID.ORG/https://orcid.org/0000-0002-7666-4730

e-mail: leonovaja@ukr.net

Дорофьєва Тетяна Іванівна: к. фіз. вих. доцент; Харківський національний педагогічний університет імені Г. С. Сковороди, вул. Алчевських, 29, м. Харків, 61000, Україна.

Дорофеева Татьяна Ивановна: к. фриз. восп., доцент; Харьковский национальный педагогический университет имени Г.С Сковороды, ул. Алчевских 29, Харьков, 61000, Украина.

Tetiana Dorofieieva: PhD (Physical Education and Sport), Associate Professor; Kharkiv G. S. Skovoroda National Pedagogical University, Alchevsky Str 29, Kharkov, 61000, Ukraine.

ORCID.ORG/0000-0001-9025-5645 